\title{
CHALLENGES AND OPTIMIZATION STRATEGY FOR FEED-IN TARIFFS OF RENEWABLE ENERGY IN CIS COUNTRIES
}

\author{
Olimjon SAIDMAMATOV ${ }^{\mathbf{1}}$, Sanaatbek SALAEV ${ }^{2}$, Bahtiyor ESHCHANOV ${ }^{\mathbf{3}}$ \\ ${ }^{1,2}$ Urgench State University, Uzbekistan \\ saidolimjon@gmail.com \\ ${ }^{3}$ Academy of Public Administration, Uzbekistan
}

\begin{abstract}
Modern life is convincing us that renewable energy technologies, policies, strategies should be disseminated all over the world to provide sustainable development. As an instrument, feed-in tariffs of renewable energy should be designed considering public finance opportunities, buying power of consumers in order to tackle administrative barriers as an optimization strategy. The authors used the comparison, data analysis and logical access methods. The paper provides evidence from leading countries in the industry, explores ongoing challenges in the application of feed-in tariff policies, analyses the optimal methodologies to give recommendations to stakeholders.
\end{abstract}

Keywords: Developing countries, feed-in tariff, investment incentives, renewable energy.

\section{INTRODUCTION}

Over the past decade, feed-in tariffs (FITs) have been a major instrument to promote the generation of electricity by means of renewable energy sources. However, feed-in tariffs have been criticised for being costly, inefficient, distortive of competitive pricing and, hence, in the long run not compatible with the creation of a single, liberalised electricity market in which renewable energy sources account for a major share in total power production (Sijm, 2002). Accordingly, FITs have driven $64 \%$ of global wind and $87 \%$ of global photovoltaic capacity. However, the majority of these installations have been installed in developed countries (UNEP, 2012).

The concept of "feed-in tariff" refers to the regulatory, minimum guaranteed price per $\mathrm{kWh}$ that an electricity utility has to pay to a private, independent producer of renewable power fed into the grid (Huber et al., 2001). For example, green energy producers received $90 \%$ of the average electricity utility rate in Germany. Thus, if consumers had paid, on average $10 € \mathrm{ct} / \mathrm{kWh}$ in 1993 , farmer using wind turbine received $9 € \mathrm{ct} / \mathrm{kWh}$ for every $\mathrm{kWh}$ fed into the grids in 1995 (IWR, 1999). 


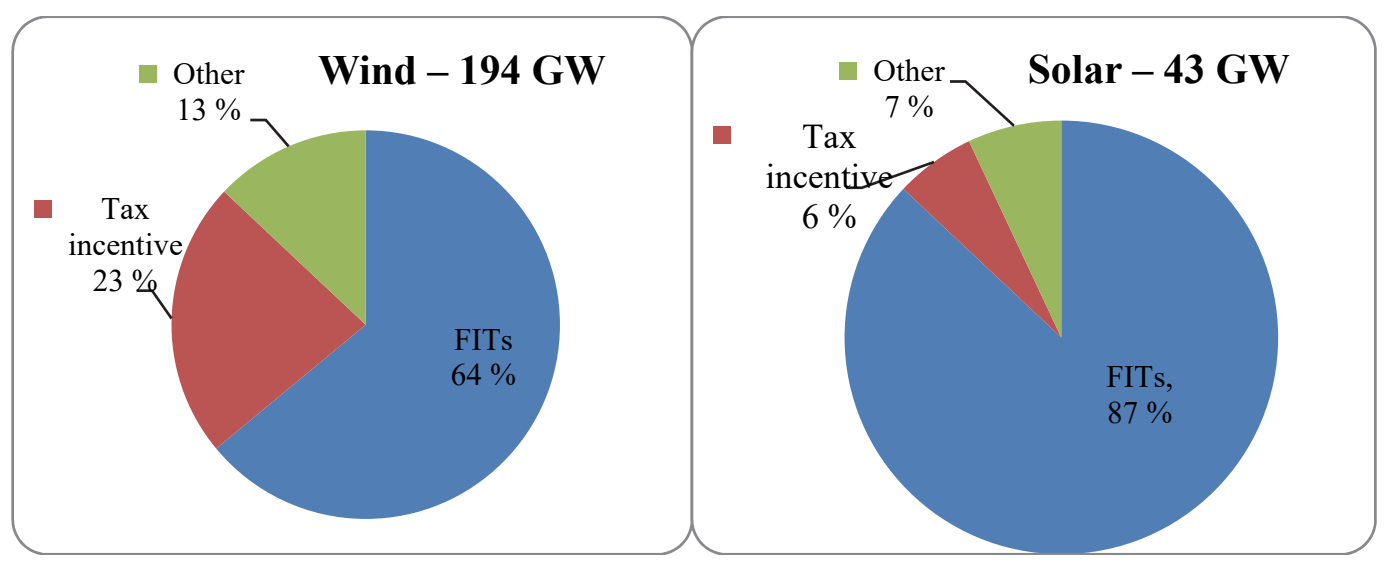

Fig. 1. Global installed capacity by incentive type (Tringas, 2011).

The core argument to apply feed-in tariffs is that they offer a high level of investment certainty to independent (risk-averse) producers of renewable electricity by guaranteeing a fixed price for each $\mathrm{kWh}$ of power fed into the grid over a certain period (i.e. 5-15 years) as well as encouraging RET capacity installation (Sijm, 2002).

\section{FIT CHALLENGES IN DEVELOPING ECONOMIES}

Increasingly, feed-in tariffs (FITs), rather than minimum percentage requirements for RETs used in the USA and Great Britain, have been argued to be a superior policy approach for promoting RETs (Rowlands, 2007). Germany, for example, has been especially aggressive about FIT implementation while total generation by RETs increased annually to over 20 terawatt-hours by 2002 which encourages RET capacity installation (Mitchell et al., 2006).

Table 1. Feed-in-Tariff Policy (World Bank, 2011)

\begin{tabular}{|l|ll|}
\hline \multicolumn{1}{|c|}{ Investment Risks } & \multicolumn{1}{c|}{ Complexity } \\
\hline$-\quad \begin{array}{l}\text { Low price, volume and balancing risks } \\
-\end{array}$ & - & $\begin{array}{l}\text { Effectiveness in terms of market } \\
\text { growth is high (subject to compliance } \\
\text { risk may arise (this risk can be } \\
\text { minimised introducing a "per area" } \\
\text { mechanism) }\end{array}$ \\
$-\begin{array}{l}\text { Designed to create stable investment } \\
\text { environment (although successive FITP } \\
\text { design adjustments may decrease }\end{array}$ & $-\begin{array}{l}\text { Sophisticated FIT design can reduce } \\
\text { infra-marginal rents } \\
\text { investors' confidence) }\end{array}$ \\
$-\begin{array}{l}\text { Predictable revenue streams for strategic support } \\
\text { of different types of RE } \\
\text { Nelp increase debt financing }\end{array}$ & $-\begin{array}{l}\text { No incentive for cost reductions } \\
\text { (entire supply chain) }\end{array}$ \\
& $-\begin{array}{l}\text { Overall cost of FITP may be high } \\
\text { (depends on FITP design and market } \\
\text { conditions) }\end{array}$ \\
\hline
\end{tabular}

Policy cost is a critical issue for renewable energy law drafters in general, and for developing countries in particular. FITs have a reputation for being inherently "expensive" policies, largely as a result of the large volume of renewable energy 
capacity that has been built in Europe under FITs. In 2009, Germany spent approximately EUR 13 billion for electricity from FITs, of which close to 5 billion represented incremental costs above average wholesale prices (Van Mark, 2010). Some developing countries may have appetite to try to follow Germany's example. China, for example, has emerged as a leading international wind market and has installed more renewable energy capacity per unit of GDP than the US, Germany and Spain (Gordon et al., 2010). Thus, each government adopts radically different FIT designs to reflect their different policy goals, renewable energy targets and national circumstances (UNEP, 2012). Potential challenges of FIT policy must be considered before the approval.

- Firstly, administrative requirement: detailed analysis is required to properly set the payment level. Detailed analysis is required to properly set the payment level at the outset. The payment level must ensure that revenues are adequate to cover project costs. If the FIT payments are set too low, little new RE development will result. And if set too high, the FIT may provide unwarranted profits to developers. To achieve the right balance across a wide range of technologies and project sizes, many levels of differentiation are used. As costs change and markets shift due to technological innovation and increasing market maturity, the FIT policy needs periodic revision to reflect evolving costs and market conditions (Karlynn et al., 2009).

- Secondly, FITs do not decrease developer's up-front costs, despite offering financial incentives for renewables. Policy makers enact investment tax credits, grants and rebates to reduce the high, up-front capital costs of RE installations that become integral part of market penetration. However, these mechanisms may not be effective at spurring broad market adoption and fail to provide stable conditions for market growth (Lantz and Dori, 2009).

- Thirdly, frequent updates to the FIT programme structure can lead to policy uncertainty. The more uncertain the policy structure, even after a few years, the riskier the RE investment is to the project financier. Consequently, investor mal leave the RE market and choose to invest in something else with less exposure to a policy risk (Chadbourne \& Parke, 2009).

FITs are difficult to define in a single sentence because they are a "package" of different regulatory and incentive policies, rather than just a single, stand-alone policy such as a tax credit or a rebate (Rickerson et al., 2011).

\section{CURRENT FIT METHODOLOGY IN EMERGING ECONOMIES}

When designing feed-in tariffs, it is important for policy makers to consider the interaction between the FIT and the existing market structure (UNEP, 2012). Developing countries represent a broad range of different electricity market structures, including state-owned monopoly utilities (e.g., in much of the Caribbean), single buyers that purchase power from IPPs (e.g., eastern European countries), and countries where wholesale power markets have been introduced 
(e.g., Argentina and Chile) (Besant-Jones, 2006). All actions oriented to renewable energy development end up with creation of FIT environment. Even cash premium of FIT can be reduced to zero - by technology improvements or the usage of other public financing mechanisms - the implementation of a strong enabling regulatory environment will remain a critical success factor. Analysing various public financing mechanisms, we believe that non-manageable risks such as the political risk or the counterparty risk can be a major hurdle for a positive investment decision from international investors (Deutsche Bank, 2011). In this case, countries will target providing financial incentives to make the renewable energy business models economically viable, rather than capital mobilisation of huge investments.

While bankers have been vilified as the cause of one of the largest financial disasters, the renewable sector has been seen as the white horse for many governments looking to emerge stronger. Despite economic downturn, investment continued in the renewable sector largely in part to government stimulus programmes that focused on developing green economies. Around the world, governments have allocated more than USD 430bn fiscal stimulus to key climate change investment themes. China and the United States lead the way (KPMG 2011).

Unless countries set governing regulations about achieving RE targets, it is hard to accomplish progress on sustainable development. World Financial Crisis 2009 convinced many developing economies that there is only one path to get rid of the climate change, financial crisis and massive unemployment all over the world. As a result, renewable energy policies are still being disseminated globally.

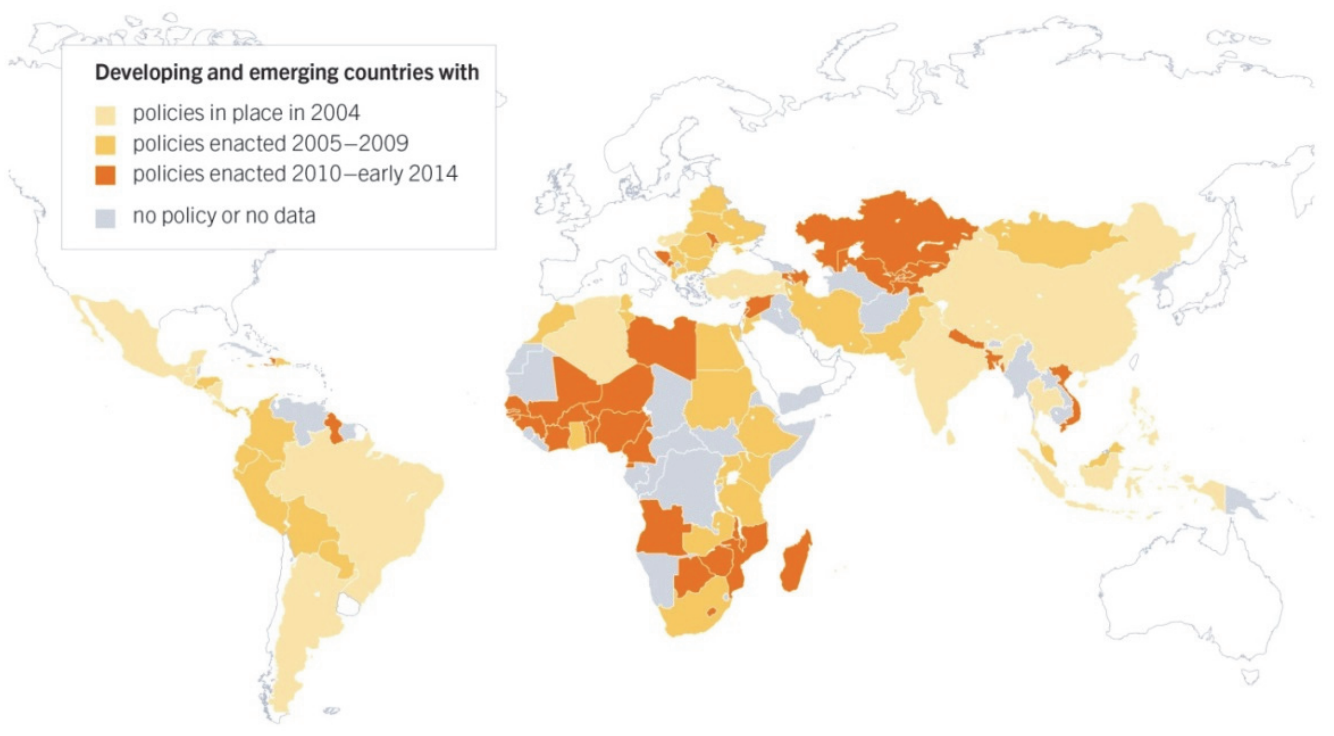

Fig. 2. Developing and emerging countries with renewable energy policies (REN21, 2014).

- Indonesia Feed-in Tariff Fund was developed by FMO and Agency of Netherlands to support geothermal development in Indonesia as the 
country possesses the world's largest geothermal resources. The fund would seek to invest private equity in the form of $\$ / \mathrm{kWh}$ payments to geothermal developers. The payment would be structured to "close the gap" between the PPA contracts that the generators are awarded and the rates they need to meet their return expectations. As fossil fuel prices rise over time, the $\$ / \mathrm{kWh}$ amount paid to the generator would eventually exceed the fixed flat guaranteed by the fund. The generator would then repay to the Fund as a return on investment (Rickerson et al., 2011).

- Global Energy Transfer Feed-in Tariff (GET FiT) is the initiative of Deutsche Bank in response to a request from the UN Secretary General's High Level Advisory Group on Climate Change Financing. The GET FiT concept outlines potential structures under which public sector resources can be used to "de-risk" renewable energy investments in developing countries (Deutsche Bank, 2011). The GET FiT concept envisions a flexible framework within which a range of different types of support could be provided to developing countries.

\section{FIT OPTIMIZATION STRATEGIES IN CIS COUNTRIES}

Ultimately, a low carbon development growth in the developing world depends on the availability of resources to finance the solutions that exhibit incremental costs while assuring FIT policy interacts and harmonises with other regulatory mechanisms (World Bank, 2011). When the application of FITs in CIS countries is analysed, it becomes clear that some market infrastructures are heritage from the Soviet Union. However, the modern world does not allow mismanaging natural resources from the viewpoint of corporate social responsibility. The following SWOT analysis identifies ups and downs of the introduction of FITs in economic conditions of CIS countries (see Table 2). In the case of Central Asia, introduction of FITs can encourage renewable energy generation from bio masses where the territory is focused on agricultural economy. Hence, totally modernised agricultural process can generate alternative energy supply to enrich the quality of electricity delivery process.

After identifying four dimensions of the energy market, optimization strategy can be formulated towards promoting renewable energy technologies with the support of feed-in tariffs.

Global evidence suggests, albeit tentatively, selling the controlling package of shares to experienced foreign firms on the sphere is more effective that keeping under the state control which leads to diversification of business portfolios of energy companies. As a result, energy efficiency, decrease in technical and non-technical losses, promotion of renewable energy technologies are listed on the top of business priorities.

Still, the rule of agency is saved in the management process in developing economies. Achieving the targeted plan approved at the beginning of the financial year and comparison with fact details at the end of fiscal year - a negative consequence of capitalistic economy. 
Table 2. SWOT Analysis (prepared by the authors)

\begin{tabular}{|l|l|}
\hline \multicolumn{1}{|c|}{ Strengths } & \multicolumn{1}{|c|}{ Weaknesses } \\
\hline $\begin{array}{l}\text { Creation of employment opportunities in the } \\
\text { renewable energy sector }\end{array}$ & $\begin{array}{l}\text { Possibility of affecting the quality of soil, water } \\
\text { and biodiversity }\end{array}$ \\
\hline Diversification of energy supply mechanism & $\begin{array}{l}\text { Economic viability dependent of regulated tariffs } \\
\text { associated with high investment costs }\end{array}$ \\
\hline $\begin{array}{l}\text { Increasing public, business awareness for } \\
\text { efficient usage from renewable energy } \\
\text { sources }\end{array}$ & $\begin{array}{l}\text { Insufficient social knowledge and awareness } \\
\text { regarding the opportunities to use renewable } \\
\text { energy and the resulting benefits }\end{array}$ \\
\hline $\begin{array}{l}\text { Storage potential and possibility of } \\
\text { generation prediction }\end{array}$ & $\begin{array}{l}\text { Lack of R\&D for decision making on regional } \\
\text { renewable energy opportunities of geographic areas }\end{array}$ \\
\hline $\begin{array}{l}\text { Economic decentralisation of energy trading } \\
\text { Threats }\end{array}$ \\
\hline $\begin{array}{l}\text { Energy and climate change priority are } \\
\text { supported on the state level }\end{array}$ & $\begin{array}{l}\text { Technology transfer problems } \\
\text { entrepreneurship in the industry }\end{array}$ \\
\hline $\begin{array}{l}\text { Active participation of small and medium- } \\
\text { sized enterprises in energy supply }\end{array}$ & $\begin{array}{l}\text { Lack of government fiscal policies to support } \\
\text { renewable energy programmes }\end{array}$ \\
\hline $\begin{array}{l}\text { Private sector enrolment in energy delivery } \\
\text { process }\end{array}$ & $\begin{array}{l}\text { Inadequate level of legislation to guide } \\
\text { entrepreneurs and investors }\end{array}$ \\
\hline
\end{tabular}

As the investment is growing in CIS countries, new established businesses highly influence the annual plans, which has not been considered in the beginning. However, the growing demand for electricity both by public and private sector, flexibility of demand concerning seasonal businesses are considered unavoidable factors of market economies.

Indeed, the market economy does not achieve expected results when the human resource is not educated with the modern concepts on related fields. For example, textbooks published several decades ago do not involve innovative aspects of RETs and opportunities for alternative energy generation to the private sector. Learning the energy sciences from the viewpoint of authoritative bodies eliminates the innovative-business aspects of the electricity generation. Experiences derived from Germany and Spain stand for updating educational aspects of the renewable energy studies in CIS countries.

\section{CONCLUSION}

Current legislation systems, fiscal constraints, rich renewable opportunities of geographic regions need scientific and practical improvements at the level of developed countries. Transition from an economy based on fossil fuels to the one based on renewable energy with the support of feed-in tariffs in Central Asian countries is quite a new concept, which requires a long-term strategy and serious commitment towards its dissemination. 


\section{REFERENCES}

Besant-Jones, J. E. (2006). Reforming power markets in developing countries: What have we learned? Washington, DC: The World Bank Group, Energy and Mining Sector Board. Retrieved Sep. 15, 2014 from http://siteresources.worldbank.org/INTENERGY/Resources/Energy19.pdf

Chadbourne \& Parke (2009). Trends in Tax Equity for Renewable Energy. Project Finance NewsWire. Retrieved Sep. 10, 2014 from http:/www.chadbourne.com/files/Publication/810dde60-3c78-4a9a9c5d-a5fae8014b4f/Presentation/PublicationAttachment/51fc06c5-1407-48ac-9dff-a605de0f58e1/ pfn0109.pdf

Design and Performance of Policy Instruments to Promote the Development of Renewable Energy: Emerging Experience in Selected Developing Countries. Washington, DC (2011): The World Bank Group, Energy and Mining Sector Board. http://siteresources.worldbank.org/ EXTENERGY2/Resources/DiscPaper22.pdf

Deutsche Bank Climate Change Advisors. (2011). GET FiT Plus: De-risking clean energy business models in a developing country context. Deutsche Bank Group. Retrieved Aug. 22, 2014 from http://europa.eu/epc/pdf/workshop/background_get_fit_plus_final_040711_en.pdf

Feed-in Tariffs as a Policy Instrument for Promoting Renewable Energies and Green Economies in Developing Countries. (2012). UNEP. Retrieved Oct. 29, 2014 from http://www.unep.org/pdf/ UNEP_FIT_Report_2012F.pdf

Gordon, K., Wong, J. L., \& McLain, J. T. (2010). Out of the running? How Germany, Spain, and China are seizing the energy opportunity and why the United States risks getting left behind. Washington, DC: Center for American Progress. Retrieved Aug. 27, 2014 from http://www.americanprogress.org/issues/2010/03/pdf/out_of_running.pdf

Huber C., Faber T., Haas R., G. Resch. (2001). Promoting Renewables: Feed-In Tariffs or Certificates. Economics. Vienna University of Technology, Institute of Power Systems and Energy, Vienna.

IWR. (1999). Vergutungssatze fur Strom aus Erneuerbaren Energien (Feed-in tariffs for electricity from renewable sources of energy). Internationales Wirschaftsforum Regenerative Energien. Retrieved Sep. 5, 2014 from http://www.uni-muenster.de/Energie/re/wf/E_Preis.html

Karlynn Cory, Toby Couture and Claire Kreycik. (2009). Feed-in Tariff Policy: Design, Implementation and RPS Policy Interactions. National Renewable Energy Laboratory. Colorado, USA. pp. 11-12. http://dx.doi.org/10.2172/951016

KPMG. (2011). Taxes and Incentives for Renewable Energy. p. 3-12. Retrieved Sep. 25, 2014 from http://www.kpmg.com/Global/en/IssuesAndInsights/ArticlesPublications/Documents/TaxesIncentives-Renewable-Energy-2011.pdf

Lantz, E., Doris, E. (2009). State Clean Energy Practices: Renewable Energy Rebates. NREL/TP620-45039. Golden, CO: National Renewable Energy Laboratory. Retrieved Oct. 7, 2014 from http://www.nrel.gov/docs/fy09osti/45039.pdf.

Mitchell, C., Baucknecht, D., Connor, P. M. (2006). Effectiveness through risk reduction: a comparison of the renewable obligation in England and Wales and the feed-in system in Germany. Energy Policy, 34, 297-305. http://dx.doi.org/10.1016/j.enpol.2004.08.004

Patricia Carneiro, Paula Ferreira. (2012). The economic, environmental and strategic value of biomass. Elsevier. 4-5.

REN21. (2012). Renewables 2012 Global Status Report. Paris: REN21 Secretariat. Retrieved Sep. 11, 2014 from http://www.map.ren21.net/GSR/GSR2012.pdf

Rickerson, W., Hanley, C., Flynn, H., \& Karcher, M. (2011). Feed-in tariff design: Implications for financing. Proceedings of the PV Rollout 2nd European American Solar Deployment Conference. February 10-11, 2011. Boston, MA.

Rowlands, I., (2007). The development of renewable electricity policy in the province of Ontario: the influence of ideas and timing. Review of Policy Research 24, 185-207. http://dx.doi.org/10.1111/j.1541-1338.2007.00277.x

Sijm, J. P. M. (2002). The Performance of Feed-in Tariffs to Promote Renewable Electricity in European Countries. Retrieved Sep. 3, 2014 from http://www.ecn.nl/docs/library/report/2002/c02083.pdf

Tringas, T. (2011). Paying for Sustainable Energy - How much more does clean energy really cost? Paper presented at the BNEF Summit. April 7, 2011. New York City. 
Van Mark, M. (2010). Cost and benefit effects of renewable energy expansion in the power and heat sectors. Berlin: Federal Ministry for the Environment, Nature Conservation and Nuclear Safety. Retrieved Sep. 5, 2014 from http:/www.bmu.de/files/english/pdf/application/pdf/hg_ausbau_ ee_2009_en_bf.pdf

\section{AUTHORS' SHORT BIOGRAPHY}
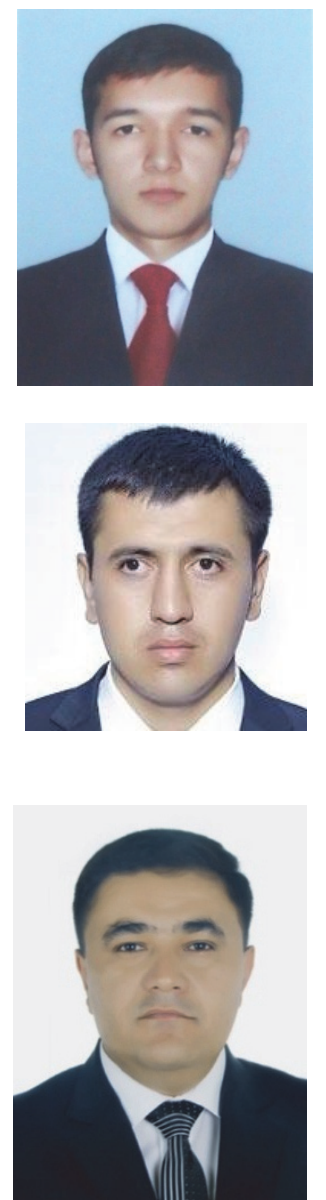

Olimjon Saidmamatov, as a Junior Researcher, is interested in different aspects of green economics: investment on renewable energy, feed-in tariffs, fiscalfinancial incentives, green energy policy of developing countries. His professional experience on territorial division of SJSC Uzbekenergo and research activity at Urgench State University stands for developing an "education-research-business" triangle for sustainable development of Uzbekistan. His foreign experiences have created opportunity for scientific relations among institutions for learning experiences of different economies. Building up economic and technical feasibility reports of solar power stations supports dissemination of research outputs in the industry.

Bahtiyor Eshchanov holds Master degree in Sustainable Technology from the Royal Institute of Technology, Sweden and $\mathrm{PhD}$ degree in Applied Economics from the Vrije Universiteit Brussels, Belgium. Currently he is an Associate Professor and Chair of the Department of Foreign Trade and Investments at the Academy of Public Administration under the President of the Republic of Uzbekistan. He has more than ten peer-reviewed publications in energy demand modelling, renewable energy, green economics and the water-energy-food nexus.

Sanaatbek Salaev is a Professor of Economics and Dean of the Faculty of Economics at Urgench State University. He has over 200 peer-reviewed articles in various disciplines. His research interests include development economics, renewable and sustainable energy and econometric analysis. He has supervised over ten researchers who have already defended their $\mathrm{PhD}$ theses. Academic meetings abroad (Austria, Germany, Poland) support him to build research networks with foreign scholars globally. 